\title{
Evidence-Based Management of Sacrococcygeal Pilonidal Sinus
}

\section{Aly Saber}

M.D Department of general surgery, Port-Fouad general Hospital, Port-Fouad, Egypt

"Corresponding author: Dr. Aly Saber Department of general surgery Port-Fouad general Hospital, Port-Fouad, Egypt, Tel: +206601223752032; Fax: +20663400848; E-mail: alysaber54@gmail.com

Received Date: 18 March 2014, Accepted Date: 25 March 2014, Published Date: 30 March 2014

Copyright: (c) 2014 Saber A, et al. This is an open-access article distributed under the terms of the Creative Commons Attribution License, which permits unrestricted use, distribution, and reproduction in any medium, provided the original author(s) and source are credited.

\begin{abstract}
A best evidence topic was arranged according to the previously accepted structured protocol. The question addressed here was if flap construction after excision of pilonidal sinus tracks showed difference in functional outcome compared to simple closure. A total of 118 papers were found using the reported search, six represented the best evidence to answer the clinical question. The authors, journal, date and country of publication, patient group, study type, outcomes and key results of these papers are tabulated. Of these six studies, one was one was systematic review of prospective randomized controlled trials and the other five were prospective randomized controlled studies. Four studies showed that flap construction was not superior to simple primary closure techniques in terms of outcome and patient satisfaction. The other two reported that excision and flap construction was better than excision and primary repair in treatment of pilonidal disease.
\end{abstract}

\section{Introduction}

The process of evidence- based medicine (EBM) for searching of the best available evidence for optimization of surgical practice is fundamental in every profession. The scope of EBM consists of converting the need of information for managing a particular case into a specific structured question which can be answered precisely [1]. Evidence-based practice should involve the integration of the best available research with the clinician's expertise, while also taking into consideration the patient's personal preferences and circumstances [2]. The evidence is usually retrieved from the literature. At the top of the hierarchy are systematic reviews of randomized clinical trials followed by randomized clinical trials (RCTs) [1]. A best evidence topic was constructed according to a structured protocol as described previously $[3,4]$ as generating a clinical scenario, posing a three-part question, performing a literature search, identifying the relevant papers, appraising the papers, tabulating the results, revisiting and updating the Best Evidence Topic or (Best BET) and conclusion [4]. The optimal treatment of chronic pilonidal sinus is still a matter of debate. Excision with primary closure, either in the midline or laterally, or with the use of flaps are usually performed and compared for length of hospital stay, pain, overall cost and recurrence rates [5].

\section{Clinical Scenario}

The treating doctor is in the out-patient clinic discussing with his patient the surgical excision of the pilonidal sinus tracks with closure of the defect whether performing simple or flap closure. The treating doctor together with his team is familiar with the different surgical methods of repair and closure of the resultant defect after excision of the sinus tracks. Every patient is concerned about the two methods of closure and its outcome. He resolves to check the literature to determine if simple closure is associated with better or worse functional outcome as compared to flap closure.

\section{Three-part question}

The three-part question is composed of:

\section{Patient characteristic \\ 2. Interventions \\ 3. Outcome [4].}

In patients who undergo surgery for pilonidal sinus in case of recurrent diseases, does simple closure as compared to flap surgery improve functional outcome?

\section{Search strategy}

Using the Google scholar engine search, the following phrases were searched for: [Pilonidal sinus surgery] AND [midline OR flap closure] AND [recurrence] AND [hospitals stay] AND [wound disruption] AND [operative time] AND [complications].

\section{Search outcome}

118 papers were found using the above-mentioned phrases. Using the criteria outlined as the Best Evidence Topic or (Best BET) in a previous publication $[3,4]$, the author selected only those papers which directly traced and compared the impact of simple closure versus flap reconstructive surgery with respect to functional outcome. This yielded a total of six papers (one was systematic review of prospective randomized controlled trials and the other five were prospective randomized controlled studies).

\section{Results}


Citation: Saber A. Evidence-Based Management of Sacrococcygeal Pilonidal Sinus. Journal of Surgery [Jurnalul de Chirurgie] 2014; 10(1): 17-20. doi:10.7438/1584-9341-10-1-4

Page 18

Table I: The results of the six papers representing the best evidence to answer this clinical question are summarized in the table.

\begin{tabular}{|c|c|c|c|c|c|}
\hline $\begin{array}{l}\text { Author, date and } \\
\text { country }\end{array}$ & Patient groups & Study type & Outcomes & Key results & Comments \\
\hline $\begin{array}{l}\text { Horwood et al. } \\
\text { February } \\
2012 \\
\text { UK }\end{array}$ & $\begin{array}{l}\text { Keywords and MeSH terms } \\
\text { included 'pilonidal disease', } \\
\text { 'primary suture/ } \\
\text { repair', 'rhomboid flap' and } \\
\text { 'limberg/ } \\
\text { modified Limberg flap' }\end{array}$ & $\begin{array}{l}\text { Systematic review of } \\
\text { randomized } \\
\text { controlled trials. } \\
\text { Level I evidence }\end{array}$ & $\begin{array}{l}\text { Six studies were included for pooled } \\
\text { analysis } \\
\text { Two studies compared 'off-midline' } \\
\text { primary suture with the Limberg flap } \\
\text { repair. } 641 \text { patients were included ( } 331 \\
\text { flap repairs). } \\
\text { Rhomboid flap excision demonstrated } \\
\text { a trend towards less disease } \\
\text { recurrence } \\
\text { lower wound infection and dehiscence } \\
\text { However, no significant difference was } \\
\text { found for pain scores, hospital stay or } \\
\text { return to work. }\end{array}$ & $\begin{array}{l}P=0.07 \\
P=0.01\end{array}$ & $\begin{array}{l}\text { This literature supports the } \\
\text { Limberg flap-repair } \\
\text { procedures over primary } \\
\text { midline suture for } \\
\text { management of primary } \\
\text { pilonidal disease. Further } \\
\text { high-quality studies are } \\
\text { necessary to compare flap } \\
\text { with primary simple } \\
\text { repairs. }\end{array}$ \\
\hline $\begin{array}{l}\text { Nursal et al. } \\
\text { February } \\
2010 . \\
\text { Turkey }\end{array}$ & $\begin{array}{l}238 \text { patients } \\
\text { VY flap method was } \\
\text { compared to } 2 \text { simple } \\
\text { primary closure techniques }\end{array}$ & $\begin{array}{l}\text { Prospective } \\
\text { randomized } \\
\text { controlled trial } \\
\text { Level II evidence }\end{array}$ & $\begin{array}{l}\text { 1- Surgical site infection } \\
\text { 2-Early wound dehiscence without } \\
\text { infection } \\
\text { 3- Mean follow-up was } 29.7 \pm 15.6 \\
\text { months. } \\
\text { 4- Survival (time without recurrence) } \\
\text { 5- In the whole group, independent } \\
\text { predictors of recurrence according to } \\
\text { logistic regression analysis were } \\
\text { younger age, recurrent disease, } \\
\text { presence of discharge on physical } \\
\text { examination, and development of } \\
\text { postoperative surgical site infection. }\end{array}$ & $\begin{array}{l}\text { NS }(P=0.129) \\
\text { NS }(P=0.665) \\
\text { NS }(P=0.648)\end{array}$ & $\begin{array}{l}\text { VYAF is not superior to } \\
\text { simple primary closure } \\
\text { techniques in terms of } \\
\text { outcome and patient } \\
\text { satisfaction. For most } \\
\text { cases, simple primary } \\
\text { closure would suffice. }\end{array}$ \\
\hline $\begin{array}{l}\text { Muzi et al. } \\
\text { Junly } \\
2010 \\
\text { Italy }\end{array}$ & $\begin{array}{l}260 \text { patients Limberg flap } \\
\text { procedure or tension-free } \\
\text { primary closure. }\end{array}$ & $\begin{array}{l}\text { prospective, standard } \\
\text { procedure, } \\
\text { controlled, } \\
\text { randomized, single- } \\
\text { center clinical trial } \\
\text { Level II evidence }\end{array}$ & $\begin{array}{l}\text { 1-Success of surgery was achieved in } \\
84.62 \% \text { of Limberg flap versus } 77.69 \% \\
\text { of primary closure. } \\
\text { 2- Surgical time for primary closure } \\
\text { was shorter. } \\
\text { 3- Wound infection was more frequent } \\
\text { in the primary closure } \\
\text { 4-postoperative pain } \\
\text { 5- time off from work and wound } \\
\text { dehiscence. } \\
\text { 6-Recurrence }\end{array}$ & $\begin{array}{l}N S(P=.079) \\
P=0.0254 \\
P<0.0001 \\
P=0.672 \\
P=0.153\end{array}$ & $\begin{array}{l}\text { Results do not show a } \\
\text { clear benefit for Limberg } \\
\text { flap or primary closure. } \\
\text { Limberg flap showed less } \\
\text { convalescence and wound } \\
\text { infection. Primary closure } \\
\text { was less painful, and } \\
\text { shorter than Limberg flap. }\end{array}$ \\
\hline $\begin{array}{l}\text { Tavassoli et al. } \\
\text { February } \\
2011 \\
\text { Iran }\end{array}$ & $\begin{array}{l}100 \text { patients } \\
\text { group I: primary repair and } \\
\text { group II: } \\
\text { Limberg flap. }\end{array}$ & $\begin{array}{l}\text { Prospective } \\
\text { randomized study. } \\
\text { Level II evidence }\end{array}$ & $\begin{array}{l}\text { A--Demographic characteristics, } \\
\text { operation time, early complication rate } \\
\text { and recurrence. } \\
\text { B- Return to work, first pain-free toilet } \\
\text { sitting, pain score and patient } \\
\text { satisfaction. }\end{array}$ & $\begin{array}{l}\text { no significant } \\
\text { difference } \\
\text { significant } \\
\text { difference }\end{array}$ & $\begin{array}{l}\text { 1-Limberg flap has similar } \\
\text { complications as the } \\
\text { primary repair method } \\
\text { earlier return to work and } \\
\text { less hospital stay, lower } \\
\text { pain score and higher } \\
\text { comfort and satisfaction } \\
\text { were the advantages of } \\
\text { the Limberg flap method. } \\
\text { Thus, this method is } \\
\text { recommended for the } \\
\text { treatment of primary } \\
\text { pilonidal disease. }\end{array}$ \\
\hline $\begin{array}{l}\text { Roshdy et al. } \\
\text { October, } 2010 \\
\text { Egypt }\end{array}$ & $\begin{array}{l}140 \text { patients } \\
\text { group I: Rhomboid flap } \\
\text { group II: } \\
\text { Primary closure. }\end{array}$ & $\begin{array}{l}\text { Prospective } \\
\text { randomized study. } \\
\text { Level II evidence }\end{array}$ & $\begin{array}{l}\text { 1- hospital stay was longer in group II } \\
\text { 2- return to work was faster in group I } \\
\text { 3- postoperative complications were } \\
\text { higher in group II } \\
\text { 4- recurrence rate was lower in group I }\end{array}$ & $\begin{array}{l}(P=.009) \\
(P=0.001) \\
(P=0.012) \\
(P=0.14)\end{array}$ & $\begin{array}{l}\text { Excision and rhomboid } \\
\text { flap is better than excision } \\
\text { and primary repair in } \\
\text { treatment of pilonidal } \\
\text { disease because it flattens } \\
\text { the natal cleft, avoid dead } \\
\text { space, healing time is } \\
\text { short, morbidity is low, } \\
\text { shorter }\end{array}$ \\
\hline
\end{tabular}




\begin{tabular}{|c|c|c|c|c|c|}
\hline & & & & & $\begin{array}{l}\text { hospital stay and low rate } \\
\text { of recurrence. }\end{array}$ \\
\hline $\begin{array}{l}\text { Dass et al. } \\
\text { August } \\
2012 \\
\text { India }\end{array}$ & $\begin{array}{l}80 \text { patients } \\
\text { 1- primary midline closure } \\
\text { 2-Limberg flap }\end{array}$ & $\begin{array}{l}\text { Prospective } \\
\text { randomized Study. } \\
\text { Level II evidence }\end{array}$ & $\begin{array}{l}\text { 1- The operative time and hospital stay } \\
\text { were longer in flap group } \\
\text { 2- The work off period was less in flap } \\
\text { group } \\
\text { 3- VAS scores } \\
\text { 4- Wound infection and disruption } \\
\text { were less in flap group. } \\
\text { 5-Seroma and hematoma were more } \\
\text { in flap group. } \\
\text { 6- Recurrence was less in flap group. }\end{array}$ & $\begin{array}{l}P>0.05 \\
P=0.0048 \\
P>0.05\end{array}$ & $\begin{array}{l}\text { The parameters in the two } \\
\text { techniques differ } \\
\text { significantly Rhomboid } \\
\text { excision with limberg flap } \\
\text { reconstruction technique } \\
\text { surely outscores elliptical } \\
\text { excision with primary } \\
\text { midline closure in certain } \\
\text { important parameters. }\end{array}$ \\
\hline
\end{tabular}

\section{Discussion}

The ideal method of treatment for pilonidal sinus would be one with minimal tissue loss, minimal postoperative morbidity, excellent cosmetic results, rapid resumption of daily activities, low cost, and a low recurrence rate [6]. However, although numerous operative treatment methods have been described, no treatment comprises all of these features [7].

Horwood et al. [8] systematically reviewed, by two independent investigators, six relevant randomized controlled trials for pilonidal disease regarding primary suture/repair and Limberg flap. A total of six hundred and forty-one patients were included in this systematic review. This literature supports the use of the rhomboid flap excision and the Limberg flap-repair procedures over primary midline suture techniques for the elective management of primary pilonidal disease but further high-quality studies are necessary to support this. The points of strength of this paper are being belonged to level I as a systematic review of randomized trials or n-of- 1 trials according to the latest Oxford Level of Evidence [3,4] and the randomized trials with poor methodology were excluded.

Nursal et al. [9] in their prospective randomized controlled study compared the V-Y advancement flap (VYAF) versus 2 simple primary closure techniques. VYAF was not superior to simple primary closure techniques in terms of postoperative complications, recurrence, and patient satisfaction and for most cases, simple primary closure would suffice. Although theoretically appealing, the VYAF technique does not offer any advantages compared to the simpler primary closure techniques. VYAF technique, however, may be needed especially in patients with large defects that cannot be mechanically approximated with primary closure. This paper reported that independent predictors of recurrence according to logistic regression analysis were younger age, recurrent disease, presence of discharge on physical examination, and development of postoperative surgical site infection. Points of strength of this paper were the sample size and the operating surgeons. According to the layered chi-square analysis, there was no difference between the type of surgery and recurrence as layered across the surgeons. Also, the results were well-tabulated and the probability values of significant were traced.

In a prospective, standard procedure, controlled, randomized, single-center clinical trial, Muzi et al. [10] represented a total of 260 patients with sacrococcygeal pilonidal disease assigned randomly to undergo Limberg flap procedure or tension-free primary closure. The primary end point of the study was clinical evidence of complete wound healing at the last follow-up evaluation without occurrence of wound infection, wound dehiscence, and sinus relapse, which were considered treatment failures. The end point has been tested using a logistic regression model, exploring the effect of the surgical procedure adjusting for age, sex, and initial presence of either acute or chronic infection. Secondary end points were days of confinement in bed, pain VAS score, and time off from work. These results did not show a clear benefit for surgical management by Limberg flap or primary closure. Limberg flap showed less convalescence and wound infection; our technique of tension-free primary closure was a day case procedure, less painful, and shorter than Limberg flap. The sample size and the independent observer were two points of strength. An independent observer, who was not from the surgical team and who was unaware of the treatment assignments, recorded all data, which included postoperative events and follow-up findings.

Tavassoli et al. [11] performed excision with primary repair as group I and rhomboid excision with the Limberg flap as group II. The demographic characteristics of their patients, early and late complications, comfort and pain score on the first and fourth postoperative day, hospital stay, time of return to work, and patient satisfaction were compared. There was no significant difference between the two groups in terms of demographic characteristics, operation time, early complication rate and recurrence. But significant difference was observed in return to work, first pain-free toilet sitting, pain score and patient satisfaction. The authors concluded that the Limberg flap has similar complications as the primary repair method, but earlier return to work and less hospital stay, lower pain score and higher comfort and satisfaction were the advantages of the Limberg flap method. Thus, this method is recommended for the treatment of primary pilonidal disease. The relatively smaller number of patients was a weak point of this paper otherwise the results were welltabulated and the probability values of significant were traced.

Roshdy et al. [12] performed rhomboid flap versus primary closure after excision of sacrococcigeal pilonidal sinus as Prospective randomized study in 140 patients. The authors stated that goal for treatment of pilonidal disease in 2 fold, the first is excising and healing with low rate of recurrence the second is minimizing patient inconvenience and morbidity after surgical procedure. In conclusion the excision and rhomboid flap is better than excision and primary repair in treatment of pilonidal disease because it flattens the natal cleft avoid dead space, healing time is short, morbidity is low, shorter hospital stay and low rate of recurrence. In this paper, the sample size 
was satisfying the results were well-written and well-tabulated and the probability values of significant were traced.

A prospective randomized study of 80 patients of sacrococcygeal pilonidal sinus was performed By Dass et al. [13] using elliptical excision with primary midline closure versus rhomboid excision with limberg flap reconstruction. Data was compiled in terms of operative period required, immediate post-operative complications, postoperative pain (VAS scores), work-off period, hospital stay and recurrences over a follow up of 3 years for the two study groups. Data thereby collected was analyzed by using Microsoft excel. The parameters in which the two techniques were found to differ significantly were work-off period, immediate post-operative complications profiles and recurrence rates. Rhomboid excision with Limberg flap reconstruction technique surely outscores elliptical excision with primary midline closure in certain important parameters. This study was limited by the smaller sample size which was considered a weak point of this paper.

\section{Clinical bottom line}

Although different surgical approaches have been used to manage sacrococcygeal pilonidal sinus, none of these approaches eliminate the postoperative morbidity and there is no agreement on the gold standard surgical treatment. Any procedure should stress well on other parameters than postoperative morbidity and recurrence such as technical simplicity, hospitalization period required, and off work period. Comparative studies of the various procedures are being increasingly published for documenting the relative superiority of one over the other. For simple non-recurrent pilonidal sinus, less invasive surgery with limited excision and primary closure could be enough.

\section{References}

1. Kassem A (2011) Concepts in evidence-based medicine. Middle East Fertil Soc J 16: 163-164.
2. Ballard K (2009) Evidence-based surgical practice: the use of intraoperative anti-adhesion agents. Surgery (Oxford) 27: 385-388.

3. McGlone ER, Khan OA, Conti J, Iqbal Z, Parvaiz A (2012) Functional outcomes following laparoscopic and open rectal resection for cancer. Int J Surg 10: 305-309.

4. Khan OA, Dunning J, Parvaiz AC, Agha R, Rosin D, et al. (2011) Towards evidence-based medicine in surgical practice: best BETs. Int J Surg 9: 585-588.

5. Rao MM, Zawislak W, Kennedy R, Gilliland R (2010) A prospective randomised study comparing two treatment modalities for chronic pilonidal sinus with a 5-year follow-up. Int J Colorectal Dis 25: 395-400.

6. Altintoprak F, Dikicier E, Arslan Y, Ozkececi T, Akbulut G, et al. (2013) Comparision of the Limberg flap with the V-Y flap technique in the treatment of pilonidal disease. J Korean Surg Soc 85: 63-67.

7. El-Sayed M (2008) A More Sensible Approach for Treatment of Pilonidal Sinus. Egy JS 27: 9-14.

8. Horwood J, Hanratty D, Chandran P, Billings P (2012) Primary closure or rhomboid excision and Limberg flap for the management of primary sacrococcygeal pilonidal disease? A meta-analysis of randomized controlled trials. Colorectal Dis 14: 143-151.

9. Nursal TZ, Ezer A, Caliskan K, Torer N, Belli S, et al. (2010) Prospective randomized controlled trial comparing V-Y advancement flap with primary suture methods in pilonidal disease. Am J Surg 199: 170-177.

10. Muzi MG, Milito G, Cadeddu F, Nigro C, Andreoli F, et al. (2010) Randomized comparison of Limberg flap versus modified primary closure for the treatment of pilonidal disease. Am J Surg 200: 9-14.

11. Tavassoli A, Noorshafiee S, Nazarzadeh R (2011) Comparison of excision with primary repair versus Limberg flap. Int J Surg 9: 343-346.

12. Roshdy H, Ali Y, Askar W, Awad I, Farid M et al. (2010) Rhomboid flap versus primary closure after excision of sacrococcygeal pilonidal sinus (a prospective randomized study) Egy J Sur $29: 146-152$.

13. Dass TA, Zaz M, Rather A, Bari S (2012) Elliptical excision with midline primary closure versus rhomboid excision with limberg flap reconstruction in sacrococcygeal pilonidal disease: a prospective, randomized study. Indian J Surg 74: 305-308. 